\title{
第34回 日本細菌学会関西支部総会
}

\author{
会 長 山口 淳二 (近畿大・医・細菌) \\ 期 日 昭和56年11月 7 日（土） \\ 会場 近畿大学医学部 円形棟 3 階 大講堂
}

\section{目次}

\section{特 別講 演}

細菌外膜の構造と機能と生合成……水島昭二(名大 · 農・農芸化学)

\section{一般講 演}

1. 寔の産生する抗菌物質の抗微生物作用 (II)ーリゾチ 一ムとの相乗作用について-……杉山孔宏，河合 一吉, 菊地幹雄, 山口淳二 (近畿大・医・細菌)

2. GLC による尿路感染症起炎菌の代謝産物分析…… ○田中美智男, 浦 敏郎, 伊藤登志子, 久城英人, 児玉順三 (国立循環器病センター・臨床検査)

3. Sphingobacterium gen. nov. \& Cytophaga john. sonae の細胞脂肪酸の組成……藪内英子, 大山昭 夫(関西医大・微生物), C. Wayne Moss (C.D.C., U.S.A.)

4. 灰化 Bacillus megaterium 芽胞飞执ける $\mathrm{Ca}$ と $\mathrm{P}$ の分布について……西原 力, 近藤雅臣（阪大. 薬・衛生)

5. Bacillus megaterium QM B1551 芽胞の $\mathrm{CdCl}_{2}$ に よる発来……只谷喜洋, 今川正良, 西原 力, 市 川富夫, 近藤雅臣 (阪大・薬・衛生)

6. 5-Fluorocytosine (5-FC), 5-Fluorouracil (5-FU) の Bioassay 法に関する知見補遺…… ○山本典巳， 伊藤富由, 谷村英紀, 大山昭夫 (関西医大・微生物), 西山直志 (関西医大・脳神経外科)

7. マゥス悪性腫瘍 MH134 への細菌内毒素の作用…… ○片山 㭌 (京都府立医大・微生物)

8. マウスリゾチームの精製怙よびその抗体を利用して の卵白リゾチームの吸収と分泌について……高橋 史郎, 富畑 滋, 樫葉周三 (奈良医大・細菌)

9. Pityrosporum 各菌種の生物学的, 血清学的性状の
比較……高橋めぐみ, 牛嶋 德, 大橋正美, 尾崎 良克 (滋賀医大・微生物)

10. 歯周ポケット内細菌叢の検索……本城範典, 山岡 昭 (大阪歯大・歯周病), 福島久典, 梅本俊夫, 佐川 寛典 (大阪歯大・細菌)

11. ブドウ糖非発酵菌によるマウス実験的尿路感染症に 関する研究……尾花芳樹, 折笠義則, 西野武志, 谷野輝雄 (京都薬大・微生物)

12. Shope 乳頭腫由来 S. epidermidis の plasmid DNA の解析……岸下雅通（京大・医・微生物，滋賀医 大・微生物)，菅原健二，伊藤洋平 (京大・医・微生 物)

13. 毒素原性大腸菌の Ent プラスミドの赤㾐菌への試 験管内伝達……竹田多恵, 北村雅哉, 竹田美文, 三輪谷俊夫 (阪大・微研)

14. コレラ毒素呫よび大腸菌易熱性エンテロトキシンに 対する抗血清による各毒素活性の中和能……多賀 関子, 山本耕一郎, 本田武司, 竹田美文, 三輪谷俊 夫 (阪大・微研)

15. コレラ菌の産生するへモリジンの測定法とその応用 ……本田武司，M. Mubashir, A. Khan，竹田美 文, 三輪谷俊夫 (阪大・微研)

16. コレラ菌执よびV. vulnificus の菌体外サルファタ 一ゼ活性について……北浦敏行, ○東 逸男, 今井 田雅示, 宮野啓一(大阪公衛研), 道家 直 (熊本衛 生公害研), 大場康寬 (近畿大・医・臨床病理), 藪 内英子 (関西医大)

17. 野鬼病菌の培養細胞内への侵入の形態学的観察...... ○佐野浩一, 植坂俊郎, 生駒一生, 三好博文, 中井 益代 (大阪医大・微生物)

18. ネズミチフス菌由来リボゾーム分画免疫マウスから 得た transfer factor 飞関する研究一第 2 報一…… ○益田収二, 喜多英二, 樫葉周三 (奈良医大・細菌) 19. 簡便法によるヒト白血球インターフェロンと抗癌㓮 
との併用効果の検討 $\cdots \cdot . \cdot$. 奥 亭, 今西二郎, 岸 田綱太郎 (京都府立医大・微生物)

20. マウス腹腔マクロファージの貪食能について（第 5 報）一二，三刺激剤投与による効果一……森田智 津子，北畠義久，横田芳武 (大阪医大・微生物)

\section{要 旨}

\section{特 別 講 演}

\section{細菌外膜の構造と機能と生合成} 水島昭二 (名大・農・農芸化学)

外膜はグラム陰性細菌の細胞表層の最外層を構成して いる膜構造体である。外界との接触面に存在する膜構造 体であるので, 細胞構造上の重要性のほか, 栄養物の取り 込み，遺伝物質の他細胞への伝達, 抗生物質を始めとす る薬剤への抵抗性, バクテリオファージの感染など, 医 学・生物学上の重要な現象に関与している。外膜はまた 組成が単純であり, 変異株の取得, 遗伝学的取り扱いが 容易なところから，構造・機能・形成などの面から生体 膜のモデル系としても注目されて和り, 現在分子レベル での解析がもつとも進んでいる生体膜の一つとなつてい る。以下大腸菌外膜についての演者らの研究を中心に,

構造・機能・生合成機構について述べる。

演者らは1968年に外膜を単離することに初めて成功し た。外膜は通常の生体膜成分であるタンパク質とリン脂 質のほかに，特有の成分としてリポ多糖をるつ。タンパ ク質としては数種類のいわゆる主要タンパク質と呼ばれ るもの (Omp C, Omp F, Omp A, 主要リポタンパク 質)のほかに特殊な物質の取り込み，ある種のファージ， コリシンなどのリセプターとなるものが知られている。 主要外膜タンパク質の多くは $\beta$-構造に富み, 非常に安 定な構造をしていて，ドデシル硫酸ナトリウム (SDS) 溶液中でも安定である。Omp C, Omp F は三量体構造 をしていて親水性低分子物質に対する誘過孔を形成して いる。Omp C, Omp F の化学構造は非常に類似してい る。共通の祖先遗伝子に由来する類似の遺伝子の産物と 考えられている。主要リポタンパク質の一部はペプチド グリカン層と共有結合して括り，外膜と同層の相互作用 に重要な役割を果していると考兄られている。最近, 数 種類の新リポタンパク質を細胞表層に発見した。これら は構造的に主要りポタンパク質と共通性を有している。
Omp C/Omp F とリポ多糖から規則正しいヘキサゴ ナルな格子構造をるつ膜構造を再構成することに成功し た。この再構成は主要リポタンパク質を結合しているぺ プチドグリカン層上で優先的に起こる。これらのことよ り，細胞表層 (外膜一ペプチドグリカン層) を構成してい る主要分子間の基本的相互作用を明らかとすることがで きた。このことは, 外膜に括いても主要構成分子の自己 集合が形態形成で主要な役割を果していることを示して いる。形態形成に括ける分子の自己集合の重要性はすで にリボソーム, 鞭毛, ウイルスなどで示されている。再 構成系は分子間の相互作用の研究に有効に用いられてい る。リポ多糖执よびその部分構造体と Omp C/Omp F タンパク質よりの再構成物の格子構造を光回析法によつ て解析した結果, タンパク質のヘキサゴナルな配列には リポ多糖の脂肪酸部分が必要なこと, 糖鎖部分はタンパ ク質分子のコンホメーションに影響を与えていることを 示すことができた。

再構成系は外膜を含む細胞表層の機能の研究にも利用 できる。Omp C, リポ多糖, ペプチドグリカン層より なる再構成表層上でファージ T4 の感染を再現すること ができた。その結果，これら表層成分の $\mathrm{T} 4$ 感染に括け る役割を明らかにすることがでさた。さらに再構成表層 の内側に細胞質膜の主要成分であるリン脂質より作成し たリポソームを入れることにより，再構成表層を貫通し たファージのコアの先端より DNA の放出を起こさせる ことに成功した。これらの研究に基づいて, 宿主細胞側 からみたファージ T4 感染過程のモデルを提出した。

外膜は細胞質膜の外側にある。このため, リボソーム 上で合成される外膜タンパク質は細胞質膜を通して分泌 されなくてはならない。この過程は外膜生合成機構の解 明と同時に, タンパク質の膜透過機構の解明の上からも 興味深いものである。タンパク質の膜透過機構に関して は Blobel らによつて提出されたシグナル仮説を中心に 活発に研究が進められている。演者らは外膜りポタンパ ク質の前駆体型から完成型へのプロセシングを阻害する 抗生物質グロボマイシンを利用して, 同タンパク質の細 胞質膜透過機構について研究を進めた。その結果, リポ タンパク質前駆体の構造およびその細胞表層での局在性 を明らかにすることができた。また，シグナルペプチド の切断に関与する酵素, 切断されたシグナルペプチドの 消化に関与する酵素N末端のアシル化に関与する酵素を 膜中に見いだすことができた。さらにシグナルペプチド の単離にも成功した。これらの成果をもとに, リポタン パク質の膜透過機構のモデルを提出した。 


\section{一般講 演}

1. 虫の産生する抗菌物翼の抗微生物作用（II）－リ ソチチームとの相乗作用について一

○杉山孔宏, 河合一吉, 菊地幹雄, 山口淳二 (近畿大 ・医・細菌)

カイコに大腸菌ワクチンを接種すると体液中のリゾチ 一么活性が上昇し, 抗菌物質 S-2, 引き続き抗菌物質 S-1が産生された。

大腸菌に対して抗菌物質 S-1 とリゾチームはなんら 相互作用を示さなかつた。一方抗菌物質 S-2 はリゾチ 一ムと明らかな相乗作用を示した。この相乗作用の機構 は，抗菌物貿 S-2 は大腸菌の外膜を培地中へ 遊離させ ること， $5 \% \mathrm{NaCl}$ 存在下で両者を作用させると大腸 菌の球状化がみられたことなどより，まず抗菌物質 S-2 が大腸菌外膜に作用し，リゾチームが外膜を通過して抗 菌作用を発現したものと考兄られた。さらに抗菌物質 $S-2$ と抗菌物質 S-1 も相乗作用を示し，これら三種の 抗菌物質は互い作用して，より強力な生体防御機構を 形成しているものと考觉られた。

\section{GLC による尿路感染症起炎菌の代謝産物分析}

○田中美智男，浦 敏郎，伊藤登志子，久城英人，児 玉順三 (国立循環器病センター・臨床検査)

尿路感染症の迅速診断を目的として GLCを用いた起 炎菌低級代謝産物の分析を行つた。

GLC 分析はアルコール，ケトン揮発性脂肪酸および 難揮発性脂肪酸の低級化合物 26 種について 2 種の充てん 剤 (FFAP, FAL-M) を用いて行つた。対象菌種は1981 年 4 月 1 日 1981年 7 月 31 日の 4 力月間に出現した有意 細菌尿起炎菌を検出率の高いものから 8 種選定し，培養 液中の代謝産物を分析した。被験菌は 4 つの代謝産物パ ターンに分類された。すなわち，大量の Ethanol，iso-

Butyric 和よび Acetoin の特異産生群 (K. pneumoniae, $S$. marcescens), 乳酸産生群 (S. faecalis, ほか), Acetic, Succinic 大量産生と Ethanol，Lactic を中等量産生す る群 (E. coli, P. mirabilis)，拈よびその他の群であ る。

\section{Sphingobacterium gen. nov. ¿ Cytophaga} johnsonae の細胞脂肪酸の組成

○薮内英子, 大山昭夫 (関西医大 - 微生物)，C. Wayne Moss (C.D.C., U.S.A.)
Sphingobacterium は Pseugomonas-like IIk-2 と呼ば れていた 1 群の菌がその菌体脂質中に高濃度のスフィン ゴ燐脂質を含有すること，扤よびその表現形質の数值分 析, DNA の GC 含量と homology の結果から提案さ れた新属である。今回 fused silica capillary column を装着した高性能の GLC により菌体脂肪酸の行つた結 果, Sphingobacterium sp. では i-15:0, i-2OH-15:0 特 よび16：1が主要脂肪酸でそれぞれ20〜30\%を占めるが Cytophaga johnsonae では i-2OH-15:0は1〜2\%にす ぎず，Flavobacterium meningosepticum では16:1が $4 \sim 6 \%$ あつた。このような脂肪酸組成は新属 $S p$ hingobacterium を提案するるら一つの根拠になると考兄 られる。

\section{4. 灰化 Bacillus megaterium 芽胞における $\mathrm{Ca}$ と} $P$ の分布について

○西原 力，近藤雅臣 (阪大・薬・衛生)

低温灰化後X線微小分析 (line 分析) することにより Bacillus megaterium の二つの芽胞グループを代表する QM B1551 芽胞とATCC19213 牙胞に拈ける Ca と P の分布を検討した。QM B1551 芽胞では $\mathrm{Ca}, \mathrm{P}$ ともに Core と Coat に分布した。Core 中の Ca はオートク レーブ処理により消失し，残存する Coat 中の Ca の分 布は $\mathrm{P}$ の分布と平行した。 $\mathrm{KNO}_{3}+\mathrm{Glucose}$ とよる発 芽では Core 中の $\mathrm{Ca}$ 以外飞 Coat 中の $\mathrm{Ca}$ - 一部消 失した。また，芽胞を酸処理後 $\mathrm{Sr}$ 処理した芽胞では exchangeable cation である Sr は Coat そのみ分布し た。一方, ATCC19213 芽胞では Ca, P ともに Core 中にのみ検出された。これらの結果と化学分析の結果を 比較することにより Core 中の Ca は Dipicolinic Acid と，また，Coat 中の $\mathrm{Ca}$ はリン酸基と結合して存在す ることなどを明らかにした。

\section{Bacillus megaterium $\mathrm{QM} \mathrm{B} 1551$ 芽胞の $\mathrm{CdCl}_{2}$} による発芽

○中谷喜洋, 今川正良, 西原 力, 市川富夫, 近藤雅 臣 (阪大・薬・衛生)

Bacillus megaterium QM B1551 芽胞を $5 \mathrm{mM} \mathrm{CdCl}_{2}$ と保温すると，耐熱性の消失，DPA の流出などほとん ぞの発芽現象が認められたが，ヘキソサミンの流出は認 められなかつた。そこで $\mathrm{CdCl}_{2}$ の cortex 溶解に対す る作用について検討した。芽胞破确物沈渣，すなわち spore integuments veronal-acetate buffer $(\mathrm{pH} 7.0)$ そケん濁し保温すると，peptidoglycan の酵素的な可溶 
化が認められた。しかし，この活性は， $\mathrm{CdCl}_{2}$ 添加では 阻害を受けなかつた。一方， $\mathrm{CdCl}_{2}$ により発芽した芽胞 から調製した integuments を $\mathrm{CdCl}_{2}$ 添加系で保温す ると, peptidoglycan の可溶化が阻害された。今後 $\mathrm{CdCl}_{2}$ の lytic enzyme 飞対する阻害をより詳しく調べ ることにより，発芽に批ける lytic enzyme の作用発現 の過程を明らかにする予定である。

\section{5-Fluorocy tosine (5-FC), 5-Fluorouracil (5-FU)}

\section{の Bioassay 法に関する知見補遺}

○山本典巳, 伊藤富由, 谷村英紀, 大山昭夫 (関西医 大・微生物), 西山直志 (関西医大 $\cdot$ 脳神経外科)

5-FC と Cytosinedeaminase (CDase) 併用による新 しい局所的な化学療法では腫瘍内に 5-FC と䎐換された 5-FU が共存するため, それぞれの組織内濃度を把握す ることは治療の上からも重要である。5-FC, 5-FU 共 存下での Bioassay による測定法を検討したところ，

Micrococcus lutens ATCC10240を用いた測定法では共 存下でも5-FC の影響を受けず, 5-FU のみの值として 求められた。Saccharomyces cerevisiae AKU4100を用 いた場合 5-FC と 5-FU 量の 総和として求められた。 中党に共存下での 5-FU は, M. luteus で測定し，5-FC 量は S. cerevisiae の測定值より 5-FU 量を減じて求め られた。実験的にラット皮下に形成させた腫崵にCDase capsule を留置し，1週間後飞 $5-\mathrm{FC} 150 \mathrm{mg} / \mathrm{kg}$ 腹腔 内に投与し，経時的に試料を Sampling して Bioassay 法を用いて 5-FC 括よび転換 5-FU 量の定量を行つたと ころ，測定法として申し分のない成績を得ることができ た。

\section{7. マウス悪性腫瘍 MH134 への細菌内毒素の作用}

○片山 㭌 (京都府立医大 · 微生物)

細菌内毒素 (以下 LPS) 飞抗腫煬作用があることは古 くからよく知られているが，その特徴は LPS の腫瘍内 投与のみでなく，その i.v, i.p 投与によつても抗腫愓 作用がじゆらぶんに示されることである。

われわれは， $\mathrm{C}_{3} \mathrm{H} / \mathrm{He}$ マウス $(10 \sim 12 \mathrm{w})$ に $\mathrm{MH} 134$ 腫瘍細胞を 皮下接種 し, 1 週後直径約 $7 \mathrm{~mm}$ の腫瘤を 形成したものに，E. coli 0127より Westphal の方法で 得た LPS の $50 \mu \mathrm{g}$ あるいは $100 \mu \mathrm{g}$ を i.p 投与すれ ば，約 4 時間後より出血が見られ，次第に壊死に移行

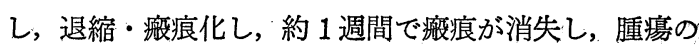
完全治癒が実群の約50\%に見られる。組織学的には, 渗 出細胞のほとんどは好中球である。
LPS の抗腫窎作用は，理論的にも，実際上にも重要 な問題点を提供している。

\section{8. マウスリソチチームの精製およびその抗体を利用し} ての卵白リソチチームの吸収と分泌について

○高橋史郎，富畑 滋，樫葉周三 (奈良医大・細菌) マウス腎臓より $4 \%$ 酶酸生食を加光, 抽出後 12000 ，回 転20分で遠沈，上清を $0.01 \mathrm{M}$, Tris で透析中和により 生じた沈殿を遠沈で除いた後, $0.1 \mathrm{M}$ の食塩を加え $\mathrm{CM}$ Sephadex C25 の Column を使用して, リゾチームを 精製した。精製したマウスリゾチーム (ML) は，F.C. A. を用いて家鬼を兔疫し得られた血清に家鬼のリゾチ 一ムを吸着し除去するため, ベンゾナイトを加えた。抗 ML 抗血清と M. lysodeikticus を含む agar plate を作 成したことで，マウス血中の 卵白リゾチーム (HL) の 測定が可能となつた。 $10 \mathrm{mg} / \mathrm{m} l \mathrm{HL} 0.1 \mathrm{~m} l$ 腹腔内投 与では HL のマウス血中濃度は 30 分ですでに最高值を 示して挌り, $200 \mathrm{mg} / \mathrm{ml} \mathrm{HL} 0.1 \mathrm{ml}$ 経口投与でも血中 に HL を認めた。胵への HL の分泌はともに 2 時間後 に最高值を示した。

\section{Pityrosporum 各菌種の生物学的, 血清学的性状} の比較

○高橋めぐみ, 牛嶋 彊, 大橋正美, 尾崎良克( 滋賀 医大・微生物)

Pityrosporum 属の $P$. orbiculare, $P$. ovale, $P$. pachydermatis 㧊よび Pityrosporum sp. の生物学的, 血清学的性状の比較検討を行つた。1）被検菌の中で $P$. orbiculare のみアスパラギン,グルタミン酸,オルニチン を利用しなかつた。2）P. ovale 以外の菌種は，増殖に ニコチン酸を必要とした。3）P.ovale と Pityrosporum $s p$. は, オレイン酸によつて強い増殖促進をうけた。 4) P. orbiculare は，乳酸により強い增殖促進を受けた が，他の菌種は，逆に增殖抑制を受けた。5）寒天ゲル 内沈降反応で, 各菌種には共通抗原と菌種特異抗原の存 在が認められた。6）走查型電子顕微鏡による細胞表層 の構造の観察で, P. orbiculare のみは凸凹のしま模様 が見られた。

\section{0. 歯周ポケット内細菌叢の検索}

○本城範典, 山岡 昭 (大阪歯大・歯周病), 福島久 典, 梅本俊夫, 佐川寛典 (大阪歯大・細菌)

䨑周ポケット内細菌の分布を Socransky らが報告し ている contineous anaerobic system を改良した方法 
で行つた結果，偏性嫌気性菌が培養可能な細菌の $90 \%$ 以 上を占めた。

偏性嫌気性菌の中では, グラム陽性桿菌の分離頻度が 高く,とくに Clostridium 属は多い人で全菌数の $85 \%$ を 占める症例もあり，すべての症例で predominant であ つた。ついで，Eubacterium の分離頻度が高かつた。し かし他の研究者が報告している Actinomyces は洼とん ぞ認められなかつた。

グラム陰性桿菌では 3 症例で $35 \%$ 前後みられ，Black pigment を有する $B$. asaccharolyticus が高頻度に分離 されたが，Fusobacterium はほとんど認められなかつ た。

\section{1. ブドウ糖非醱酵菌によるマウス実験的尿路感染症 に関する研究}

○尾花芳樹，折笠義則，西野武志，谷野輝雄（京都薬 大・微生物)

$P$. aeruginosa 6 株, P. cepacia 5 株, P. maltophilia 5 株，A. calcoaceticus 10 株を用い，マウス実験的上行 性尿路感染症の作製について検討を行つたところ，P. aeruginosa のすべての株に扔いて腎に多数の感染菌が認 められ，組織学的検討からも強い感染性を有することが 判つた。A. calcoaceticus では 10 株中 3 株飞感染性が認 められたが，その他の菌株抢よび P. cepacia，P. maltophilia ではあまり感染性が強くないことが判つた。また これらの感染性は，白血球の食食殺菌および膀睄上皮細 胞への付着能と関連性があることが認められたが，腹腔 内感染による毒力，血清殺菌素に対する感受性，尿中で の増殖能などとは明らかな関連性が認められなかつた。

\section{Shope 乳頭腫由来 $S$. epidermidis の plasmid} DNA の解析

○岸下雅通 (京大・医・微生物，滋賀医大・微生物), 菅原健二，伊藤洋平 (京大・医・微生物)

ワタオノウサギ乳頭腫より分離された EM 高度而性 $(800 \mu \mathrm{g} / \mathrm{m} l$ 以上), 水溶性赤褐色色素産生性 S. epider midis の plasmid DNA を, アガロースゲル電気泳動 で検討した。 plasmid DNA は, Warren らの方法 （1975）で溶菌し，Hirt の方法にて抽出した。EM 而 性ならびそ色素産生能脱落株での plasmid DNA の存 続状態には，変化がなかつた。分離菌には，少なくとも 3 種の cc-plasmid DNA (M.W. 1.6, 3.0, $4.9 \times 10^{6}$ daltons)を保有していたがここれらは，倍量体の関係に はなかつた。ワタオノウサギの乳頭腫では, ウイルス (cc 型 DNA, M.W. $5 \times 10^{6}$ daltons) が産生されてい るが, 分離菌の plasmid DNA は, EcoR I ならびに Hind III の消化の結果よりここれと異種のものであつ た。

\section{3. 毒素原性大腸菌の Ent プラスミドの赤痢菌への}

\section{試験管内伝達}

○竹田多恵, 北村雅哉, 竹田美文, 三輪谷俊夫（阪大 ・微研)

大腸菌の産生する LT や ST 〔と類似のエンテロトキ シンが異種の細菌，たとえばサルモネラや腸炎エルシニ アなどによつてる産生される。しかし，現在まで，LT やST を担う Ent プラスミドは大腸菌からしか検出さ れていない。われわれは大腸菌の Ent プラスミドが他 の腸内細菌にも伝撻可能な性質のものであるかどう.か調 ベた。Donor として E. coli LSA-44 〔Ent (LT, ST) : Tn3 (Apr) ]を用い, Shigella dysenteriae に伝達を試 みたところ約 10-3 の頻度で Ent プラスミドが伝達され た。しかも赤痢菌体内で産生された LT ST は大腸 菌のそれぞれと免疫学的に類似のものであつた。かつ赤 痢菌体内でもEnt プラスミドは安定に保持されていた。

14. コレラ毒素および大晹菌易熱性エンテロトキシン に対する抗血清による各毒素活性の中和能

○多賀関子，山本耕一郎，本田武司，竹田美文，三輪 谷俊夫 (阪大・微研)

毒素原性大腸菌の 易熱性 エンテロトキシン (LT) と コレラ毒素 (CT) と対する各抗血清から，抗 LT 特異 抗体，抗 $\mathrm{LT}$ 共通抗体，抗 $\mathrm{CT}$ 特異抗体，抗 $\mathrm{CT}$ 共通 抗体を得た。この 4 種の抗体の毒素活性中和能をウサギ 皮膚血管透過性試験と $\mathrm{CHO}$ 細胞の形態変化で測定し た。その結果 1) 抗血清の homologous の毒素活性の

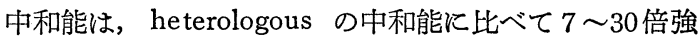
かつた。2）特異抗体では homologous の毒素活性中和 に必要な量の 400〜800 倍を用いても， heterologous の 毒素活性を中和しなかつた。3）共通抗体の中和能は毒 素が homologous, heterologous にかかわりなく著明な 差がなかつた。

15. コレラ菌の産生するへモリジンの測定法とその応 用

O本田武司，M. Mubashir, A .Khan, 竹田美文，三 輪谷俊夫 (阪大・微研)

エルトール型コレラ菌の産生するへモリジンを指標と 
してコレラ菌菌株を判別するために，へモリジン産生量 の定量的な検査法の開発を試みた。3\%グリセロール加 ハートインフュージョン・ブロスを $100 \mathrm{ml}$ のフラスコ 飞 $5 \mathrm{~m} l$ 入れコレラ菌を植え, $37 \mathrm{C}$ で 48 時間静置培養し た後，遠心 $(12,000 \mathrm{rpm} \times 10$ 分） 乙，その上清 $0.9 \mathrm{~m} l$ 飞 $5 \%$ 羊赤血球 $0.1 \mathrm{~m} l$ と $5 \% \mathrm{NaN}_{3} 0.1 \mathrm{~m} l$ を加えて

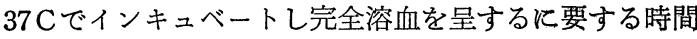
を測定して，ヘモリシシ産生量の指標とした。その程度 に応じてコレラ菌を 1〜 6 型に分類し感染経路解析の試 みをした。従来の定性的なへモリジン検査法に比べて， 本法は定量性があり，コレラ菌感染経路の解析やへモリ シンの産生量と臨床症状との関連性の解析などに有用な 検査法の一つとなろう。

16. コレラ菌および V. vulnificus の菌体外サルファ ターゼ活性について

北浦敏行，○東 逸男，今井田雅示，宮野啓一（大阪 公衛研), 道家 直 (熊本衛生公害研), 大場康寛 (近畿 大・医・臨床病理)，藪内英子 (関西医大)

V. vulnificus および $V$. cholerae 01 群は例外なくド デシル硫酸ソーダ (SDS) 0.1\%和よび Polymyxin B 100 単位 $/ \mathrm{m} l$ を含む新しい分離寒天上では，halo を伴つた 集落を形成するため，他のビブリオ属との鑑別が容易で あり，この現象は而菌種が菌体外サルファターゼ活性を 持つて拈り，培地中に含まれる SDS がこれによつて加 水分解されたため生じたドデシルアルコールが，水に不 溶性であるため，これが培地を白濁させると結論され た。ペプトンを含まないゲラチンと可溶性殿粉の増菌培 地とこの分離平板の組み合わせによつて, 貝類, 汽水, 海水などから効率よく $V$. vulnificus を分離することが でき，またこの特徴はコレラ菌の分離にも有効であると 考えられたので，培地処方を含めて報告した。

\section{7. 野鬼病菌の培養細胞内への侵入の形態学的観察}

○佐野浩一, 植坂俊郎, 生駒一生, 三好博文, 中井益 代 (大阪医大・微生物)

野鬼病菌は細胞内増殖を示すが，その侵入過程はよく 知られていない。今回は本菌の培養細胞への侵入機序を 見るために野鬼病菌生菌, 同死菌，ポリスチレンラテッ クス，緑膿菌死菌を $\mathrm{HeLa}$ 細胞，Chang 肝細胞に接 種，経時的に光顕および電顕を用いて観察した。その結 果, ポリスチレンラテックス, 野鬼病菌死菌, 緑膿菌死 菌とも培善細胞内に入ることから，野鬼病菌生菌の場合 もとの侵入機序に培養細胞の貣食機構が大きな役割を果
していると考学られた。な抒鬼病菌生菌の場合は，貪 食の際に培養細胞の食胞膜が菌の増殖の過程に拈いて消 失するが，それ以外のるのでは消失することはなかつ た。

18. ネズミチフス菌由来リボソーム分画免疫マウスか ら得た transfer factor に関する研究一第 2 報一

○益田収二，喜多英二，樫葉周三 (奈良医大・細菌)

Sal. typhimurium LT2 から精製した ribosomal fraction にて, $\mathrm{ddY} \cdot \mathrm{C}_{3} \mathrm{H}$ マウスを免疫し, 脾蔵より transfer factor を抽出, その生物学的活性, 化学的組 成について検討した。その結果，(1) 遅延型過敏反応を passive に transfer する。(2) 脾蔵, footpad での増菌 抑制効果があること。(3)感染防御能を付与するが，その 効果は一過性であること。(4) $\mathrm{C}_{3} \mathrm{H}$ マウス由来の transfer factor により，5つの分画を得た，拈の拈のの分画を O.D. $220 \sim 310 \mathrm{~nm}$ の UV 連続 spectrum でみると, 核酸由 来の pattern を示す分画が一つ存在することがわかつ た。

現在, fraction した各分画の生物学的活性, 化学的 組成をさらに検討中である。

19. 簡便法によるヒト白血球インターフェロンと抗癌 剤との併用効果の検討

○奥 亭，今西二郎，岸田綱太郎（京都府立医大・ 微生物)

抗癌剤併用時の細胞増殖抑制効果を検討するための方 法には生細胞数計測法, ${ }^{3} \mathrm{H}$-チミシン取り込み法, 色素 取り込み法などがある。しかし，いずれの方法も煩雑で あったり放射性同位元素を用いたりしなければならない など種々の欠点がある。わたしたらはニュートラル・レ ッドを用いた色素取り込み法を応用して簡単に細胞増殖 抑制効果を調べる方法を開発し，ヒト白血球インターフ エロンと他の抗癌剤 (BLM, MMC, ara C) との併用効 果を検討した。その結果，次のような所見を得た。ヒト 白血球インターフェロンと抗癌剤を同時に併用し，3日 間培養した時にのみ拮抗現象が観察された。他の処理法 すなわち，どちらか一方の薬剤で前処理して後，残りの 薬剤で処理した場合には，相加効果が認められた。

20. マウス腹腔マクロファージの領食能について（第 5 報) 一二，三刺激剤投与による効果一

○森田智津子，北畠義久，横田芳武（大阪医大・微生 
物)

刺激凨をマウス腹腔内に投与して得られたマクロファ 一シ (MP) の in vitro と和影異物食食能を常在 MP と比較した。刺激剤としてチオグリコレート培地 (TGC)，流動パラフィン拈よび $2 \%$ ガイン液を用い た。異物として前回までの報告と同じく緑膿菌（P. aeruginosa NCTC，10490 株) (Ps.) を用いた。結果と して MGC 処置群が収率がもつとも良く, 常在 MP の
約 2 倍得られ，次いで流動パラフィン，カゼインであつ た。光顕標本により常在 MP と比して TGC, 执よび カゼイン処置群で Ps. の取り込多数に差がなく，流動 パラフィンでは時間の経過とともに貪食数が増加し, 特 に 1 時間では 20 個以上のものが約 $20 \%$ に見られた。一 方 SEM の観察では刺激剤処置群も常在 MP \& Ps. の とらえ方には差が見られなかつた。 